Open Access

\title{
Effect of corruption and political instability on enterprises' innovativeness in Ethiopia: pooled data based
}

\author{
Arega Shumetie $^{1^{*}}$ and Mulugeta Damie Watabaji ${ }^{2}$
}

\author{
* Correspondence: ashueconomist@ \\ gmail.com \\ ${ }^{1}$ Department of Economics, Debre \\ Markos University, Po.Box. 169, \\ Debre Markos, Ethiopia \\ Full list of author information is \\ available at the end of the article
}

\begin{abstract}
The aim of this study is to investigate the effects of corruption and political instability on Ethiopian enterprises' innovativeness based on pooled data from 644 and 848 enterprises (manufacturing, retailing, and non-retailing services) surveyed in 2011 and 2015, respectively by the World Bank. Both descriptive statistics and structural equation modeling (SEM) were employed for the data analysis. The descriptive statistics results revealed the decline in Ethiopian enterprises' innovativeness during 2015 in comparison with 2011. Similarly, Internet access and training provided to permanent employees somehow decrease over the study period, which are believed to be unfavorable for enterprises' innovativeness. The model results revealed significant greasing effects of corruption, power outage, time and capital budget for R\&D activities, exposure to foreign markets, provision of formal training to permanent employees, and number of employees with high school education on Ethiopian enterprises' innovativeness. However, political instability has significant negative effects on enterprises' innovativeness in the country. The study implies that quality of labor, access to training and foreign markets, and political stability are covariates that seek special attention of enterprises and other concerned parties to enhance innovativeness.
\end{abstract}

Keywords: Innovativeness, Corruption, Political instability, Enterprises, Ethiopia

\section{Introduction}

In the view of many scholars, innovation refers implementation of new or significantly improved goods, services, process, marketing and organization methods, and/or the combination of any of these by enterprises to gain competitive advantages (Goedhuys, Janz, \& Mohnen, 2014; Makanyeza \& Dzvuke, 2015). It involves the introduction of new output or major improvement made to the existing products/services to meet dynamic customers' demands (Barasa, Knoben, Vermeulen, Kimuyu, and Kinyanjui (2017); Jeroen \& Patrick, 2006). Innovation encourages economic growth and plays a key role that paves the way for the development of most countries in the world (Mowery \& Oxley, 1995). Productivity, employment rate, and annual sales growth tend to be consistently higher for countries with more innovators (Rupert, Jordi, Jacques, \& Bettina, 2014). According to Crespi and Zuniga (2011), innovation assures enterprises' success in both developing and developed countries as it stimulates competitiveness.

(c) The Author(s). 2019 Open Access This article is distributed under the terms of the Creative Commons Attribution 4.0 International License (http://creativecommons.org/licenses/by/4.0/), which permits unrestricted use, distribution, and reproduction in any medium, provided you give appropriate credit to the original author(s) and the source, provide a link to the Creative Commons license, and indicate if changes were made. 
Tamer (2016) reaffirmed the same idea saying that new products, production processes, marketing and organizational methods, if introduced, would increase competitive advantage and efficiency of enterprises. Egbetokun, Richmond, Oluseye, and Edward (2016) defined innovation broadly within the contexts of developing countries to include adoption of new processes and technologies developed elsewhere and possible modifications made to existing products. The focus of this study is to analyze innovativeness (both product and process) of Ethiopian enterprises using pooled survey data for 2011 and 2015 collected by the World Bank.

Corruption is another key concept considered in this study. Past studies conceptualize corruption as the misuse of public authority for personal gains (Aurora, Teixeira, \& Luís, 2015; Neudorfer \& Theuerkauf, 2014). It is an informal payment that negatively affects enterprises' innovativeness (Daniel, 2012). In the view of Bardhan (1997), corruption is an act of malfeasance by government officials for personal enrichments while performing tasks entrusted to them by the general public. The payment of bribe is one dimension of corruption (Daniel, 2012). Corruption can also be defined as dishonest or illegal behavior of government officials (Hammed, 2018). The underdevelopment of Africa and the wide spread political instability in the continent are connected with the high rate of corruption as its politicians, leaders, and public servants illegally collect wealth using public office for private gains (Hammed, 2018). Owoye and Bissessar (2014) noted that corruption persists in the continent as long as a large proportion of the population engages in it and less benefit goes to the few honest Africans. The problem persists in the continent as long as the governance system perpetrated by dictators and the system remains weak without institutional checks and balances.

In Ethiopia, as well, though its impact on enterprises innovativeness was not studied yet, Megiso (2007) noted the negative effect of corruption on the on-going poverty alleviation programs of the country. According to the author, corruption is rampant and a treat to the country's development and democratization process. The same study went further to mention poor governance, lack of accountability and transparency, low level of democratic culture, lack of clear regulations and authorizations, low level of institutional control, and extreme poverty and inequality as major causes of corruption in Ethiopia. Though empirical evidences are not made available, authors hypothesize corruption to be one of the root causes of the high magnitude of political instabilities the country encountered in the recent couple of years.

Few past studies have tried to establish relationships between corruption and enterprises' innovativeness. For instance, a study conducted by Mahagaonkar (2008) concluded that corruption has a significant negative association with enterprises' product innovativeness while it facilitates market innovativeness. A study conducted by Gayle, Candace, and Christopher (2012) also came up with similar findings that corruption reduces enterprises' innovativeness. How does the persistent corruption affect Ethiopian enterprises' innovativeness?

Political instability is another building block of the conceptual construct designed for this study. According to several past studies, political instability can be considered as a critical bottleneck for the innovation and overall economic development of many countries (Gayle et al., 2012; Hammed, 2018; Leydesdorff \& Meyer, 2006; Varsakelis, 2006). Innovation prone political systems tend to be highly suitable for industrialization and 
strongly support institutional and technological advancement (Carlsson, 2006). Frequent occurrence of large-scale shocks and social unrest, civil war, and violence deters enterprises' innovativeness (Feng, 1997). In politically unstable countries, it can hardly be possible to attract foreign direct investments, which is the key for enterprises' innovativeness (Globerman \& Shapiro, 2003). The frequent happening of political instability accompanied with massive corruption result into deep-rooted underdevelopment and poverty in Africa (Hammed, 2018).

Research findings consistently reveal that political instability deters countries from supporting fundamental innovative activities of their enterprises. It is evident that political instability harms the quality of scientific institutions and hampers enterprises' innovativeness. As noted by Gayle et al. (2012), political instability causes budget shortage for $R \& D$ activities at national and enterprise levels, and weakens collaborations between academicians and practicing enterprises, lessens government spending on technology, and deteriorates quality of education. Although there are few studies conducted on enterprises' innovativeness, none of them considered corruption and political instability simultaneously as explanatory variables and they did not address endogeneity of the former variable. Moreover, research efforts to address the endogeneity problem make tiny proportion, and this study employed structural equation modeling (SEM) to this problem for further investigation. The study constructed SEM considering enterprises' innovativeness and political instability as latent variables which is a peculiarity of this study and an original contribution to the literature.

Based on the above premises, the study aims to (1) investigate the importance of governments' effectiveness on enterprises' innovativeness through mediator variables: corruption and political instability; (2) examine the direct or indirect effects of corruption on enterprises' innovativeness; (3) investigate the effect of enterprises' characters on their innovativeness; and (4) examine how access to infrastructure affects enterprises' innovativeness in Ethiopia.

The rest of this study is structured as follows. The second part of the paper provides the conceptual framework and the theoretical underpinning of the research hypotheses. The third part contains detail discussions on data sources and types and method of analysis. Results of the data analysis and discussions are presented in the fourth part of the paper. Finally, conclusions, recommendations, and limitations of the study were provided in the fifth section. All the references cited in the body of the study listed under section six.

\section{Conceptual framework}

This study is guided by the conceptual framework provided under Fig. 1. The figure depicts that government effectiveness affect enterprises' innovativeness through the two mediator variables, corruption and political instability. On the other hand, the conceptual framework hypothesizes that enterprises' innovativeness could directly affected by their characteristics (legality status, participation in international, and domestic markets) and access to infrastructural facilities (internet access, power supply, access to working capital, and training provided to employees). The framework perceived that corruption-free and politically stable business environment is conducive for enterprises' innovativeness. Although different factors could influence enterprises' innovativeness, 


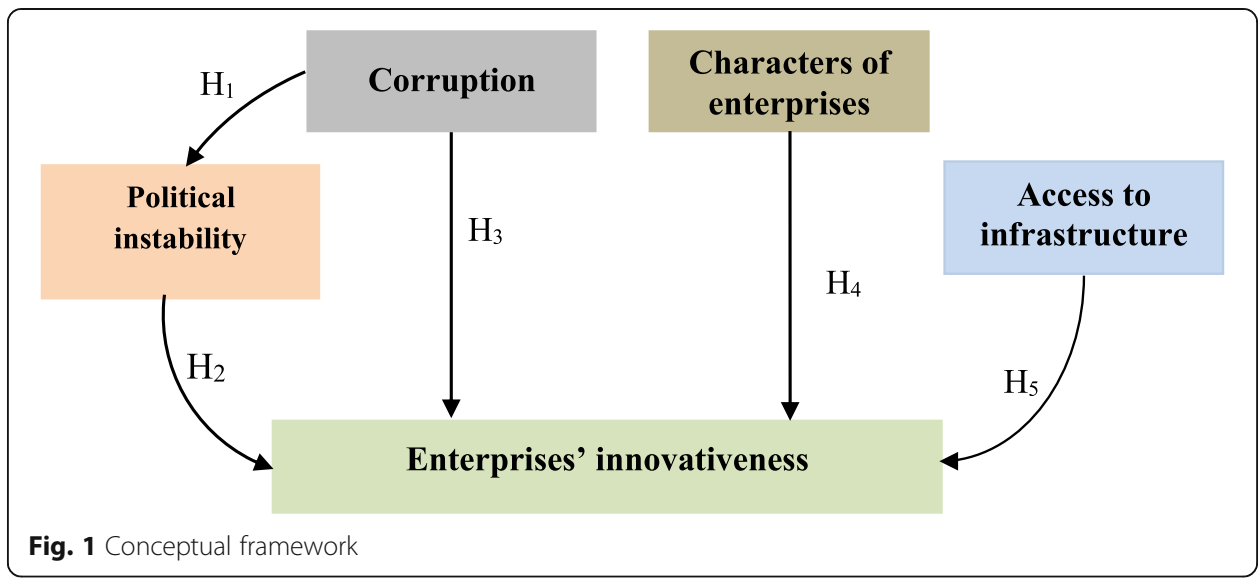

only those included in the conceptual framework were given attention in this study for the reasons narrated in the introductory section.

For this study, five hypotheses were formulated based on the conceptual framework presented in Fig. 1. Alike the conceptual link depicted in the framework, Abu, Abd Karim, and Azman (2015), Mauro (2004), and Tamer (2016) have the view that corruption hurts economic growth by causing political instability and lowering the accumulation of human capital. In the view of Neudorfer and Theuerkauf (2014), corruption distorts the formal operation of institutions and widens economic inequalities among different groups of the society which eventually lead to political instability. Similarly, Farzanegan and Witthuhn (2017) noted a positive correlation between corruption and political instability particularly in countries where there is high proportion of youth population compared to elder ones. On the other hand, special treatment and accommodation of private interests through corruption can moderate political instability (Fjelde, 2009). According to the institutional economics literature, corruption is commonly defined as an abuse of public power or authority for private benefits (Rodriguez, Siegel, Hillman, \& Eden, 2006). Corruption may take the forms of bribery, extortion, embezzlement, and fraud (Lambsdorff, 2007). In the view of some researchers, political instability accounts for high level of corruption in many countries (Campbell \& Saha, 2013; Zhang, Cao, \& Vaughn, 2009). Edame (2001) defined corruption as an anti-social behavior conferring improper benefits contrary to legal and moral norms. This study adopted the definition provided by the World Bank (1997) which is the "use of public office for private gain" in the form of bribery and extortion between two parties. The fact that literature exist in support of both positive and negative effects of corruption on political instability calls for need to conduct in depth investigation of the causal relationship between them in Ethiopia. Thus, this study hypothesizes the following.

\section{H1: Corruption has positive effect on political instability}

Political instability involved the understanding of differences between the power of the national elite that rule the country and that of non-elite (Hammed, 2018). One of the major components of political system is institutional environment in which enterprise operate. Political instability has negative and significant association with the national system of innovation (Gayle et al., 2012). Innovative enterprises are considered 
to be relatively more sensitive to the institutional environment than non-innovative ones (D'Estea, Rentocchinib, \& Jurado, 2010). Therefore, this study hypothesizes as follows for effect of political instability on innovativeness of Ethiopian enterprises.

H2: Political instability has negative effect on enterprises' innovativeness

Rising corruption and political instability contribute to underdevelopment through adversely affecting government revenue, production, savings, investment, growth, and income distribution in West Africa (Abu et al., 2015). Alonso and Garcimartín (2013) identified that corruption reduces enterprises' innovativeness through increasing distrust and uncertainty in governmental institutions and the entire business environment. On the other hand, Goedhuys, Pierre, and Tamer (2016) mentioned that corruption would rather have greasing and accelerative effect on enterprises' innovativeness particularly in countries with poor governance systems. With more interest on innovation, DiRienzo and Das (2015), using the Global Innovation Index, has found that corruption significantly harms innovation activities across countries. As Bardhan (1997) pointed out that high rates of corruption in politically unstable countries always creates entry barriers for foreign-owned enterprises. This fact may discourage free flow of ideas and limits the innovativeness of local enterprises as well. Based on this premises, the following hypothesis is constructed.

H3: Corruption in the government system has negative effect on enterprises' innovativeness

Barasa et al. (2017) suggested that enterprises organized as corporations with legal personality reported greater innovativeness compared to organization without legal personality. The number of patent registrations is taken as a measure of innovated output (Gayle et al., 2012). Ownership structure and legal status have strong association with firm performance (Colin \& Abbi, 2016). Therefore, the study proposed the following hypothesis about Ethiopian enterprises.

H4a: Enterprises' legality has a positive effect on their innovativeness

Palangkaraya (2012) found a statistically and economically significant positive correlation between participation in international markets and enterprises' innovativeness. Participation in the export market would initiate enterprises to be innovative. Similarly, Crespi, Chiara, and Jonathan (2008) identified that firms' participation in export market affects their innovativeness. Firm-level analysis revealed that there is a positive relationship between innovation and international competitiveness (Halpern, 2007; Montobbio, 2003). Innovation and international market orientation have strong interaction (Małgorzata, 2015). Some argue that innovativeness may drives internationalization, which is known as self-selection hypothesis. However, others forward a valid hypothesis for enterprises from developing countries is learning-by-exporting, which is acceptable for firms that commonly adopt the existing technology rather than investing on new ones. Thus, this study formulated the following hypothesis for Ethiopian enterprises. 
H4b: Enterprises' participation in international markets has positive effect on innovativeness

Independent media and access to information in African states can foster transparency, accountability, and informed participation (Oluwaseun \& Faith, 2013). Easy access to information that could create awareness about both the external and internal environment would enable enterprises to be competent enough in the world market. Therefore, this study makes the following hypothesis in connection to Internet access on enterprises' innovativeness in Ethiopia.

H5a: Access to Internet has positive effect on enterprises' innovativeness

Inadequate infrastructure has been a major constraint on businesses' innovativeness in East Africa (Salami, Kamara, \& Brixiova, 2010). This study perceived that Ethiopian enterprises encounter similar circumstances, and proposes the following hypothesis.

H5b: Sustainable power supply has positive effect on enterprises' innovativeness

Le (2012), and Nguyen and Luu (2013) concluded that lack of access to working capital is a critical constraint on enterprises' innovativeness. Lower access to credit is often considered one critical constraint to firm's growth and performance (Buyinza \& Bbaale, 2013). Similarly, this study proposes the following hypothesis for Ethiopian enterprises.

H5c: Access to working capital has positive effect on enterprises' innovativeness

Osoro, Vermeulen, Knoben, and Kahyarara (2016) noted that interaction of external (from the outside World) and internal (from internal activities) sources of knowledge have greater impact on enterprises' innovativeness (product and process) in Tanzania when the two knowledge sources complement each other than when utilized separately. On the other hand, Goedhuys et al. (2016) argued that knowledge acquisition by employees and/or top managers facilitate enterprises' innovativeness. Other studies show that the probability and intensity of export is positively influenced by research and development, and successful innovations (Gourlay \& Seaton, 2004). In the view of Barasa et al. (2017), allotment of large amount of resources and strong institutional support for research and development activities affected enterprises' innovativeness significantly. Thus, following hypothesis could be tested.

H5d: Active engagement in research and development activities has positive effect on enterprises' innovativeness

\section{Research methodology}

\section{Type and source of data}

The study examined the effect of corruption and political instability on enterprises' innovativeness considering secondary data collected in 2011 and 2015 by the World Bank from 644 and 848 enterprises (manufacturing, retailing, and non-retailing services) in 
the two respective survey years. The surveys comprised of issues such as process and product innovation, access to production inputs, political instability, good governance, corruption, annual sales, employment level, and other aspects of enterprises. The organization considered nationally representative sample enterprises in the different surveys to collect reliable data. The World Bank considered similar questionnaires in the successive surveys, which could make easy to pool the data at the different surveys.

\section{Method of data analysis}

Based on findings of past research works (Bogliacino \& Pianta, 2010; Waldemar, 2012), determinants of enterprises' innovativeness include a set of variables such as website ownership, research and development activities, foreign ownership, foreign-licensed technology, formal employee training, and educational attainment of the top manager. Given this, Sergey and William (2009) examined interaction of entrepreneurship, innovation, and corruption through manipulating feasible generalized least squares (FGLS), which do not allow addressing endogeneity problem between explanatory variables. Gayle et al. (2012) identified impacts of political instability and pro-business market reforms on national systems of innovation using seemingly unrelated regression (SUR), which manage multiple equations, but does not address endogeneity problem and behavior of latent explanatory variable. Having this, our study used both descriptive and econometric methods of data analysis whereby the former includes simple statistics like average, ratio, tabulation, and graphical presentation of the data. Additionally, the study used structural equation modeling (SEM) to examine the effect of political instability, corruption, and other covariates on innovativeness of Ethiopian enterprises. This model allows to addressing the endogeneity problem of political instability, which is highly dependent on corruption and other covariates.

\section{Structural equation model}

Innovation within an enterprise may be measured using any of the four dimensions: product, process/technology, organizational, or marketing innovation. However, this study considered the first two (product and process) dimensions to measure Ethiopian enterprises' innovativeness and identified effect of political instability, corruption, and other covariates. Thus, the dependent variable, enterprises' innovativeness, constructed as a dummy variable of value 1 if the enterprise has product and/or process innovation, 0 otherwise. The explanatory variables considered in SEM took different formats, which means some of them were endogenous and the others exogenous.

The mathematical interaction of covariates in the study is constructed based on the conceptual framework presented in Fig. 1. SEM is a multivariate regression (i.e., multi-equation) model, wherein the response variables in one equation may appear as a predictor in the other (Hailu, Peter, \& Bonita, 2005). The authors argued that the variables in SEM may have reciprocal effect, either directly or indirectly and/or through one over the other as an intermediary. In general, SEM captures effect of exogenous variables on the endogenous ones, and the interaction among endogenous variables.

The essence of SEM reveals that the dependent variable $(Y)$ is a function of some other explanatory variables $(Z)$, and a purely random disturbance $u$. Note that the variables $Y$ are assumed to be interdependent. The objective of modeling is to explain the 
values of observable vector-valued variable $Y, y=\left(y_{1}, \ldots, y_{g}\right)$. This circumstance implies that there is endogeneity problem in constructing SEM, and there are two or more dependent variables. The explained variables denoted by $y_{\mathrm{i}}$ are endogenous and the explanatory denoted by $z_{\mathrm{i}}$ are exogenous. The $i$ th observation should satisfy the set of implicit equation:

$$
f\left(Y_{\mathrm{i}}, Z_{\mathrm{i}}, \quad \mu_{\mathrm{i}} \mid \theta_{\mathrm{i}}\right)=0
$$

Where $f$ is a structural model and $\theta_{\mathrm{i}}$ is a parameter in the model output. Assume that there is a unique solution value of $Y_{\mathrm{i}}$ for every $Z_{\mathrm{i}}$ and $\mu_{\mathrm{i}}$. Then it is possible to rewrite the equation explicitly with $Y_{\mathrm{i}}$ as function of $Z_{\mathrm{i}}$ and $\mu_{\mathrm{i}}$ :

$$
Y_{\mathrm{i}}=f\left(Z_{\mathrm{i}}, \quad \mu_{\mathrm{i}} \mid \pi \mathrm{i}\right)
$$

Equation 2 is the reduced form of the structural model, where $\pi_{\mathrm{i}}$ is a vector of parameters for the reduced form equation that are functions of $\theta_{\mathrm{i}}$ (Cameron \& Trivedi, 2005). The reduced form is generated by solving the original structural model for the endogenous variables $Y_{\mathrm{i}}$ at the given $Z_{\mathrm{i}}$ and $\mu_{\mathrm{i}}$. If the objective of modeling structural equation is inference about $\theta$ (the original function coefficient), then Eq. (1) provides a direct route, which involves estimation of the original structural model. However, Eq. (2) also provides an indirect route to infer about $\theta$, since $\pi$ is function of $\theta$. Based on the above equations, a simple causation of parameters in the original structural model would be specified having two endogenous variables $Y_{1}$ and $Y_{2}$, and a single exogenous variable $Z_{1}$, one stochastic variable linking $Y_{1}$ and $Y_{2}$, and one definitional identity linking all three variables in the model:-

$$
\left.\begin{array}{c}
Y_{1}=\gamma_{1}+\beta_{1} Y_{2}+\mu_{1}, 0<\beta_{1}<1 \\
Y_{2}=\alpha_{1} Y_{1}+\theta_{1} Z_{1}+\varepsilon_{2}
\end{array}\right\}
$$

In this model, $\mu_{1}$ is a stochastic disturbance that is independent of $Z_{1}$ having a well-defined distribution. The parameter $\beta_{1}$ is a coefficient, which reveals interaction of $Y_{2}$ and $Y_{1}$. The variable $Z_{1}$ is exogenous and therefore its variation is induced by external sources that could be regard as interventions, which have a direct effect on $Y_{2}$ and indirect effect on $Y_{1}$ through the first equation. Thus, the formal model with all the explanatory variables could be constructed as:

$$
\begin{aligned}
\mathrm{IP}_{i j}= & \beta_{0}+\beta_{1} C_{j}+\beta_{2} \mathrm{PI}_{j}+\beta_{3} \mathrm{TL}_{j}+\beta_{4} \mathrm{IL}_{\mathrm{ij}}+\beta_{5} \mathrm{IA}_{\mathrm{ij}}+\beta_{6} \mathrm{FT}_{\mathrm{ij}}+\beta_{7} \mathrm{AC}_{\mathrm{ij}}+\beta_{8} \mathrm{FO}_{\mathrm{ij}}+ \\
& \beta_{9} \mathrm{RD}_{\mathrm{ij}}+\beta_{10} \mathrm{QL}_{\mathrm{ij}}+\beta_{11} \mathrm{EP}_{\mathrm{ij}}+\varepsilon_{i}
\end{aligned}
$$

Where:

$$
\begin{array}{ll}
\mathrm{IP}=\text { Innovation of enterprise } j & \mathrm{FT}_{\mathrm{j}}=\text { Formal training to employees of enterprise } j \\
\mathrm{C}_{\mathrm{j}}=\text { Corruption in enterprise } j & \mathrm{AC}_{\mathrm{j}}=\text { Access to working capital for enterprise } j \\
\mathrm{PI}_{j}=\text { Political instability for enterprise } j & \mathrm{FO}_{\mathrm{j}}=\text { Formal or licensed operation of enterprise } j \\
\mathrm{TL}_{\mathrm{j}}=\text { Total labour employed by enterprise } j & \mathrm{EP}_{\mathrm{j}}=\text { Electric power outage at enterprise } j \\
\mathrm{IL}_{\mathrm{j}}=\text { Import license for enterprise } j & \mathrm{RD}_{\mathrm{j}}=\text { Engagement in R\&D activities by enterprise } j \\
\mathrm{IA}_{\mathrm{j}}=\text { Access to Internet by enterprise } j & \mathrm{QL}_{j}=\text { Percentage of qualified labour in enterprise } j
\end{array}
$$

The structural model of the study considers an endogenous variable, political instability (PI), which could be aggravated if there is high corruption (C) in the country (see Table 1). 
Table 1 Definition of basic variables

\begin{tabular}{|c|c|c|}
\hline Variable & Operational definition & Variable type \\
\hline Innovation & $\begin{array}{l}\text { It was constructed considering product and/or } \\
\text { process innovation. }\end{array}$ & $\begin{array}{l}\text { It was a dummy variable taking a value of } 1 \text { if } \\
\text { the enterprise innovative, } 0 \text { otherwise. }\end{array}$ \\
\hline Corruption & $\begin{array}{l}\text { It reflects perception and/or actual experiences } \\
\text { what the enterprise managers or owners faced } \\
\text { from government officials who have the } \\
\text { interest of misusing public authority for } \\
\text { personal gains. Moreover, do enterprise owners } \\
\text { or managers deliberately participate in } \\
\text { corruptive activities? }\end{array}$ & $\begin{array}{l}\text { It was a dummy variable taking a value of } 1 \text { if } \\
\text { the enterprise managers or owners } \\
\text { participate in corruptive activities, } 0 \text { otherwise }\end{array}$ \\
\hline $\begin{array}{l}\text { Political } \\
\text { instability }\end{array}$ & $\begin{array}{l}\text { It refers the likelihood of violence, terrorism, } \\
\text { harassing, and any of unjust activities that } \\
\text { disturb the normal day-to-day activities of firms } \\
\text { in Ethiopia in each survey year. }\end{array}$ & $\begin{array}{l}\text { It took value of } 1 \text { if enterprises experienced } \\
\text { any sort of political instability, or else } 0 .\end{array}$ \\
\hline $\begin{array}{l}\text { Enterprises' } \\
\text { characters }\end{array}$ & $\begin{array}{l}\text { This variable includes enterprise type and } \\
\text { international market participation as a core } \\
\text { issue. }\end{array}$ & $\begin{array}{l}\text { - The enterprise type was categorical variable } \\
\text { considering manufacturing enterprises as a } \\
\text { base. } \\
\text { - On the other hand, a value of } 1 \text { was } \\
\text { assigned if the enterprise participates in } \\
\text { international markets. }\end{array}$ \\
\hline $\begin{array}{l}\text { Infrastructure } \\
\text { access }\end{array}$ & $\begin{array}{l}\text { This variable includes: } \\
\text { - Access to training, Internet, and working } \\
\text { capital } \\
\text { - Number and type of employees } \\
\text { - Sustainable power supply } \\
\text { - Time and capital budget for research and } \\
\text { development }\end{array}$ & $\begin{array}{l}\text { - Dummy variable based on access to those } \\
\text { facilities. } \\
\text { - Continuous variable (number and } \\
\text { proportion of graduate workers. } \\
\text { - Dummy variable based on availability and } \\
\text { outage. } \\
\text { - Proportion of time and capital budgeted for } \\
\text { research and development within each } \\
\text { enterprise. }\end{array}$ \\
\hline
\end{tabular}

$$
\mathrm{PI}_{\mathbf{j}}=\theta_{0}+\theta_{1} \mathrm{C}_{\mathrm{j}}+\mu
$$

Thus, the final functional form of SEM model of this study was:

$$
\left\{\begin{array}{c}
\mathrm{IP}_{i j}=\beta_{0}+\beta_{1} C_{j}+\beta_{2} \mathrm{PI}_{j}+\beta_{3} \mathrm{TL}_{j}+\beta_{4} \mathrm{IL}_{j}+\beta_{5} \mathrm{IA}_{j}+\beta_{6} \mathrm{FT}_{\mathrm{j}}+\beta_{7} \mathrm{AC}_{\mathrm{j}}+\beta_{8} \mathrm{FO}_{j}+ \\
\beta_{9} \mathrm{RD}_{\mathrm{j}}+\beta_{10} D S_{j}+\beta_{11} E P_{j}+\varepsilon \\
\mathrm{PI}_{\mathrm{j}}=\theta_{0}+\theta_{1} C_{\mathrm{j}}+\mu
\end{array}\right.
$$

\section{Results and discussions}

\section{Descriptive results}

The World Bank considered the four different types (referring size) of enterprises (micro, small, medium, and large) as a sample in 2011 survey. Table 2 shows that the

Table 2 Type of enterprises in the different scale

\begin{tabular}{llll}
\hline Type of enterprises & 2011 & 2015 & Change \\
\hline Micro & 4.50 & 0.00 & -4.50 \\
Small & 25.16 & 34.67 & 9.51 \\
Medium & 33.54 & 32.78 & -0.76 \\
Large & 36.80 & 32.55 & -4.25 \\
\hline
\end{tabular}

Source: Enterprise Survey Word Bank 2011 and 2015

Note: all the values in the above table are in percentage (\%) 
proportion of micro-, medium-, and large-sized enterprises reduced in 2015 compared to the number in 2011. The size of the firm is determined by the number of employees: 5 to 19 (small), 20 to 99 (medium), and 100 or more (large) (World Bank, 2015). Firms with less than five employees (micro-enterprises) and firms that are 100\% state-owned were ineligible for the survey in 2015. This circumstance results in zero micro-enterprises in 2015 survey (see Table 2). In the first survey, the proportion of small enterprises were $25.16 \%$ and the proportion increased significantly to $34.67 \%$ in 2015 , which may be due to graduation of micro enterprises to the next level. The proportion of medium- and large-sized enterprises decreased in the second survey year.

Table 3 shows that the two round surveys of the World Bank considered larger proportion of enterprises from manufacturing (42.86 and 44.46\% in 2011 and 2015, respectively).

The proportion increased (1.6\%) in the second survey, which may be due to the national level increment of enterprises' participation in that sector. Moreover, proportion of enterprises that participate in non-retail service sector showed better increment (3.56\%) in the second survey compared to the first (see Table 3).

Table 4 shows that there was reduction in the percentage of enterprises that have product and process innovation in 2015 as compared to what it was in 2011. This circumstance implies that intention and actual practice of enterprises in Ethiopia toward innovation is reducing, which may be due to internal or external factors and instabilities. This circumstance indicates that enterprises, which operate in the country, are trying to improve market access that would directly increases revenue as well as income within short period. They rather not fret on the way how and what to produce, which would improve sales and net income consistently.

Table 5 discloses that $47.12 \%$ of the surveyed Ethiopian enterprises had access to Internet connection in 2011 and the percentage decreased to $30.76 \%$ in 2015 . The table also reveals that proportion of enterprises' that spend on research and development activities to be innovative decreased in 2015 compared to what it was in 2011. This circumstance indicates that enterprises have no intention and effort toward innovation, and they do not pave the way to be innovative.

The percentage of enterprises that allocate sufficient time and working capital for research and development activities reduced by 12.6\% in 2015 from what it had been in 2011 (20.75\%). Similar situation observed regarding the situation of organizing formal trainings for permanent employees of enterprises (30.89\% in 2011 and 14.79\% in 2015).

Table 6 reveals that corruption was rated as very severe problem by $5.25 \%$ of the enterprises in 2011; however, the percentage increased to $9.34 \%$ in 2015 . Only $5.73 \%$ of the enterprises rated the problem as major in 2011 and the percentage of enterprises that had the same affliction increased to $7.20 \%$ in 2015.

Table 3 Composition of enterprises in the different sectors

\begin{tabular}{llll}
\hline Type of enterprises & 2011 & 2015 & Change \\
\hline Manufacturing & 42.86 & 44.46 & 1.6 \\
Retail services & 26.86 & 21.70 & -5.16 \\
Non-retail services & 30.28 & 33.84 & 3.56 \\
\hline
\end{tabular}

Source: Enterprise Survey Word Bank 2011 and 2015

Note: all the values in the above table are in percentage (\%) 
Table 4 Percentage of enterprises with innovation in the two surveys

\begin{tabular}{llll}
\hline Year & Product & Process & Both combined \\
\hline 2011 & 42.88 & 43.59 & 54.66 \\
2015 & 37.03 & 27.24 & 41.98 \\
Change & -5.85 & -16.35 & -12.68 \\
\hline
\end{tabular}

Source: Enterprise Survey Word Bank 2011 and 2015

Note: values in the table are percentages (\%)

Political instability was very severe for $2.04 \%$ of sampled enterprises in 2011, but the percentage of enterprises with the same suffering decreased to $1.60 \%$ in 2015 (see Table 6). This situation implies that corruption is the main concern compared to political instability for the enterprises. Thus, how significant is the overall effect could be verified through manipulating econometric models.

\section{Regression results}

\section{Model fitness test}

The root mean squared error of approximation (RMSEA), the standardized root mean squared residual (SRMR), and the coefficient of determination (CD) are commonly used parameters to measure SEM model goodness of fit. The RMSEA, which is an important post optimality test of SEM regression, shows that the value (0.024) in this model is below the threshold level of 0.08 (see Table 7). This test labels the SEM as a best fit model if the lower bound of the 90\% confidence interval is below 0.05 and the upper bound is above 0.10 (Browne and Cudeck, 1993). The $p$ value for a test of close fit (pclose) is 0.998 that is between 0.9 and 1, which provides strong evidence to accept SEM model as best fit for the dataset based on the statistical report, RMSEA value. Bentler (1990) noted that the Comparative Fit Index (CFI) and Tucker-Lewis Index (TLI) values of 1 or closer indicate good model fit to the dataset. Accordingly, the SEM model provided CFI and TLI values of around 0.90. Additionally, the SRMR value of zero reveals a perfect fit of SEM model, and the value in this study (0.011) shows the better fitness of the SEM for the datasets. The CD, which is the $R^{2}$ of the model, shows perfect fit of the model when it is 1 or $100 \%$ (Hancock \& Mueller, 2006). However, for pooled data with a more cross-sectional dimension like what this research has, the CD values are often quite less than the threshold level.

\section{Model result and discussion}

Table 8, the SEM model result, presents different outcomes including effect of different covariates on the core variable of interest, enterprises' innovativeness, and the other endogenous variable, political instability. The study considered political instability as an explanatory variable for enterprises' innovativeness while it is dependent on corruption.

Table 5 Percentage of enterprises with access to inputs

\begin{tabular}{llll}
\hline Description & 2011 & 2015 & Change \\
\hline Internet access & 47.12 & 30.76 & -16.36 \\
Time and capital budget for R\&D & 20.75 & 8.15 & -12.6 \\
Formal training for permanent employees & 30.89 & 14.79 & -16.1 \\
\hline
\end{tabular}

Source: Enterprise Survey Word Bank 2011 and 2015

Note: All the values in the above table are in percentage (\%) 
Table 6 Severity of corruption and political instability for enterprises in Ethiopia

\begin{tabular}{llllll}
\hline $\begin{array}{lllll}\text { Extent of } \\
\text { the } \\
\text { problem }\end{array}$ & 2011 & & 2015 & \\
\cline { 2 - 3 } & Corruption & Political instability & & Corruption & Political instability \\
\hline No problem & 65.13 & 85.53 & 52.65 & 82.14 \\
Minor & 14.49 & 8.49 & 16.79 & 9.98 \\
Moderate & 9.39 & 2.20 & 14.02 & 4.31 \\
Major & 5.73 & 1.73 & 7.20 & 1.97 \\
Very severe & 5.25 & 2.04 & 9.34 & 1.60 \\
\hline
\end{tabular}

Source: Enterprise Survey Word Bank 2011 and 2015

Note: values in the table are percentage (\%)

The study assumed that corruption has direct effect on political instability of the country and the covariate further affects Ethiopian enterprises' innovativeness in 2011 and 2015. Moreover, variables such as enterprises' characters and access to infrastructural facilities were also considered in the regression.

Most of the explanatory variables have the expected directional effects on the outcome variable of the regression. Based on the model result, participation of enterprises in corruptive activities enhanced their innovativeness (see Table 8). The covariate has significant positive effect on enterprises' innovativeness in Ethiopia, which may allow them to break the public bureaucracy easily. Positive effect of corruption on innovation only as a "greasing" mechanism to bypass the bureaucratic obstacles of business permits (Tamer, 2016). Enterprises in Africa easily bypass the lengthy and time-consuming bureaucracy through corruption. This finding corroborates with the hypothesis of Goedhuys et al. (2016) "corruption would have greasing and accelerative effect on enterprises' innovativeness in countries with poor governance systems". Corruption may serve as a mechanism to bypass the bureaucratic obstacles related to obtaining the necessary business permits and licenses for product innovation. Moreover, Meon and Sekkat (2005) argued that corruption may be desirable economically since it enables to bypass lengthy and inefficient government services. Some firms get motivated to pay some additional "informal payments" that smoothen the way to overcome time wasted on many bureaucratic procedures (Fisman \& Svensson, 2007). The "get things done" behavior has proven that corruption may secure easier business opportunities through corruptive practices (e.g., briberies, informal gifts etc.), notably in countries where institutions are extremely ineffective (Meon \& Weill, 2010).

In the African context, government services can only be accessed through corrupt strategies (Mahagaonkar, 2008), which is a manifestation of poor governance. This infers that corruption has a greasing effect that paves the way and trigger on enterprises' innovativeness in the continent. In Africa, it is obvious that enterprises with strong financial capacities get involved in corruption to facilitate their business activities effortlessly and the logic may hold true in Ethiopia. The model result (Table 8) implies that enterprises that participate in corruptive activities can easily breakout the lengthy bureaucratic obstacles in accessing government services. These findings incongruous to the view of Goedhuys et al. (2016) that corruption has a direct negative effect on the likelihood that a firm is an innovator. Lorenzo and Núñez-cacho (2013) also argued that corruptive behavior can affect innovation indirectly through the abundance of nepotism, which creates an under-diversification within the firm and 
Table 7 Model fitness test of SEM results

\begin{tabular}{lc}
\hline Description & Values \\
\hline Root mean squared error of approximation (RMSEA) & 0.024 \\
Pclose value (Probability RMSEA $\leq$ 0.05) & 0.998 \\
Comparative fit index (CFI) & 0.978 \\
Tucker-Lewis index (TLI) & 0.951 \\
Standardized root mean squared residual (SRMR) & 0.011 \\
Coefficient of determination (CD) & 0.293 \\
\hline
\end{tabular}

makes it unattractive for external skills that trim down innovative behavior of enterprises.

National systems of innovation are most likely to flourish in developed, politically stable countries and less likely to prosper in historically unstable countries. Generally speaking, political stability has been recognized as a precondition for vibrant national systems of innovation (Gayle et al., 2012). Politically unstable countries do not allow enterprises to introduce new products and processes. The other covariate hypothesized to affect Ethiopia enterprises' innovativeness is political instability, which is expected to have a significant negative effect. As it was hypothesized earlier, enterprises'

Table 8 SEM regression result (dependent variable enterprises' innovativeness)

\begin{tabular}{|c|c|c|c|}
\hline Dependent variables & Explanatory variables & Coefficient & $\begin{array}{l}\text { Std. } \\
\text { error }\end{array}$ \\
\hline \multirow{16}{*}{$\begin{array}{l}\text { Enterprises' innovativeness (product and/or } \\
\text { process) }\end{array}$} & Corruption & $0.1596^{* * *}$ & 0.0267 \\
\hline & Political instability & $-0.0683^{* *}$ & 0.0338 \\
\hline & Power outage & $0.1492^{* * *}$ & 0.0379 \\
\hline & Time and capital for formal research & $0.2236^{* * *}$ & 0.0389 \\
\hline & Access to training & $0.1997^{* * *}$ & 0.0317 \\
\hline & Internet access & $0.1898^{* * *}$ & 0.0273 \\
\hline & $\begin{array}{l}\text { Proportion of high school graduate } \\
\text { workers }\end{array}$ & $0.0097^{* *}$ & 0.0043 \\
\hline & Access to foreign market & $0.1190^{* *}$ & 0.0459 \\
\hline & Type of enterprise & $0.0531^{* * *}$ & 0.0143 \\
\hline & Number of total employees & $-0.0005^{*}$ & 0.0003 \\
\hline & Working experience in the enterprise & -0.0014 & 0.0019 \\
\hline & City where the enterprise planted & $-0.0484^{*}$ & 0.0261 \\
\hline & Size of the enterprise & -0.0155 & 0.0147 \\
\hline & Working capital from non-Bank & 0.0012 & 0.0017 \\
\hline & Perception for tax & 0.0332 & 0.0264 \\
\hline & Constant & 0.1245 & 0.0797 \\
\hline \multirow[t]{2}{*}{ Political instability } & Corruption & $0.2730^{* * *}$ & 0.0196 \\
\hline & Constant & $0.0609^{* * *}$ & 0.0130 \\
\hline Var (e. enterprises' innovation) & & 0.2014 & 0.0077 \\
\hline Var (e. political instability) & & 0.1300 & 0.0050 \\
\hline LR test of saturated: $x^{2}$ & & 23.28 & \\
\hline Prob $>x^{2}$ & & 0.000 & \\
\hline Number of enterprises & & 1380 & \\
\hline
\end{tabular}

Note: innovation in this model refers to both product and process innovations $*^{* * *}, *$, and ${ }^{*}$ refers 1,5 , and $10 \%$ level of significance 
innovativeness is negatively influenced by politically instability in Ethiopia (see Table 8). Politically unstable countries tend to be less predictable; therefore, enterprises are less capable to attract all the required working capital and skilled manpower from abroad (Globerman \& Shapiro, 2003) and hence they could be less innovative. Weak institutions with fragmented constellations of actors tend to hinder innovation (Egbetokun, Siyanbola, \& Adeniyi, 2007; Iizuka, Mawoko, \& Gault, 2015; Muok \& Kingiri, 2015). Political instability is beyond the capacity of individual enterprises to control and by-pass it easily, which may be the logic behind the sandy effect of the problem on innovativeness in Ethiopia.

Other factors like enterprises' characteristics and access to infrastructures have significant effect on enterprises' innovativeness in Ethiopia as to the model result. An uninterrupted electric power supply found to be one of the most important limiting factors in the enterprises' operations and it so determines innovativeness. However, the model result presented below came up with positive and significant interaction between frequent power outage and enterprises' innovativeness in Ethiopia. This may be due to the fact that enterprises' managers and employees could utilize the downtime created by the power outage for thinking about how to come up with new product/ processes. The responsiveness of the enterprises' innovativeness to power outage is significant both economically (coefficient $=0.149$ ) and statistically (significant at $1 \%$ ). The positive interaction between power outage and enterprises' innovativeness may further be justified when we observe the significant and positive relationship between times allocated for research and development activities, and enterprises' innovativeness.

Formal research and development activities are one of the most decisive factors of innovation (Godin, 2013). Table 8 reveals that time and capital allotted for research and development activities has significant positive effect on enterprises' innovativeness in Ethiopia. Enterprises that spent more time and capital budget for research and development are found to be more innovative than those spending less for the same cause. Godfred, Charles, and Mark (2018) identified that access to cost-effective credit/ loan system or an overdraft facility has a positive effect on productivity of manufacturing firms in Sub-Saharan Africa. Since innovation is a function of time allotted to think about new product/process development, the regression coefficient for this variable perfectly justifies the same logic. This covariate has significant effect (coefficient of 0.2236) in influencing enterprises' innovativeness in Ethiopia.

Investing more in Africa's infrastructure is critical to spurring innovation (Egbetokun et al., 2016). Access to formal training to permanent employees of enterprises and Internet connectivity significantly affect enterprises' innovativeness. Formal trainings for the employees, certification, and the wide-use of internet have high importance to firm-level innovation (Waldemar, 2012). Tarus and Sitienei (2015) also identified that human and social capital are critical in the innovation process and so firms that neglect these capitals are unlikely to realize the potential to innovate. This implies that access to both facilities would increase awareness of the managers and employees of the enterprises about latest technological innovations worldwide which in turn motivates them to innovate.

Additionally, increment in the proportion of high school graduate workers in the overall labor force would have positive and significant effect on enterprises' innovativeness. Firm performance in Africa is determined by educational level, the 
skills and experience of the owners, managers, and the workforce (Williams \& Abbi, 2016). This indicates that increasing the number of qualified labor that may be eager to adopt new technologies within an enterprise could enhance innovativeness. Contrary to this, employing huge labor within the enterprises would reduce innovativeness of enterprises in Ethiopia, which may be due to diseconomies of scale and overutilization of fixed inputs. Successive increment of employing the variable input, labor, on the fixed input, capital, may result in over utilization of the latter input.

Moreover, enterprises' exposure to the outside world measured through enterprises participation in foreign markets has significant and positive effect on enterprises' innovativeness. With regards to the direction of causality between participation in foreign markets and enterprises' innovativeness, there is an evidence for both forward and backward causation in the services rendering enterprises. Moreover, evidence suggests that enterprises' innovativeness may lead to a high probability of participating in the foreign markets, a backward causality (Palangkaraya, 2012). The exposure of Ethiopian enterprises to the foreign markets where there is tough competition from experienced and strong enterprises would force the local enterprises to be innovative to survive and become competent. Positive effect of competition is more evident when one observes how innovative enterprises that poorly perform in the domestic markets are.

The regression results reported in Table 8 also shows that type of enterprises has significant and positive effect on enterprises' innovativeness in Ethiopia. The regression categorized enterprise into manufacturing and others (service rendering and none) on which the former was the base. Based on the model result, manufacturing enterprises are more innovative as compared to the other type of enterprises.

Moreover, the model result revealed that corruption significantly aggravates political instability within the country as to the model result. Both internal and external sources of innovation are conditioned by institutional factors (the rules and norms), economic infrastructures, and nature of education (Mudombi \& Muchie, 2014). Based on the model results on Table 8, once again the study argued that severe corruption in a given country leads to more politically instability.

\section{Conclusions and policy implications}

\section{Conclusion}

Both product and process innovativeness of enterprises in Ethiopia reduced in 2015 as compared to what it was in 2011. In line with this, Internet access, formal training for permanent employees, the time and capital budget to enhance research and development capacity of employees reduced in 2015 for the sampled enterprises in Ethiopia.

The severity and extent of both corruption and political instability increased with the going of time as to the World Bank enterprise survey in Ethiopia.

The econometric model result of the study reveals that Ethiopian political instability affected enterprises' innovativeness negatively and significantly. The recurrent political instability does not allow enterprises to introduce new products and/or process in their business process.

The analysis also shows that corruption has significant positive effect on Ethiopian enterprises' innovativeness. The covariate has a greasing effect on the wheel of 
innovativeness for enterprises operating in the country. This finding is unexpected and it should be further examined by future researchers to generalize about Ethiopia, Africa and other developing countries.

Additionally, the SEM result showed that power outage, time, and capital budgeted for research and development activities positively affect enterprises' innovativeness in Ethiopian.

Awareness of enterprises about recent development and technological issues has significant positive effect on their innovativeness. In connection to this, access to Internet, training, and foreign markets have positive and significant effect on enterprises' innovativeness in Ethiopia.

Moreover, the intensive corruption in the government service delivery would directly aggravate the persistent political instability in Ethiopia. The tough and complex corruption participation of government officials, and enterprise owners and managers significantly aggravate long-lasting political instability in the country. The direct linkage of corruption and political instability implies that corruption has both direct and indirect effect on enterprises' innovativeness.

\section{Policy implications}

The findings of the study implicates to the policymakers that the labor employed in Ethiopian enterprises should have easy access to Internet, trainings, education, and the foreign markets to facilitate the innovativeness.

Policies that open the ways and directions for enterprises to participate in foreign markets should be there, and these circumstances could create opportunities that enhance innovativeness.

There must be policy backing to increase the amount of time and budget devoted for $R \& D$ activities since $R \& D$ are instrumental to enhance the innovativeness of Ethiopian enterprises.

Anti-corruption measures should be prior agenda for Ethiopian government in order to create a white noise and politically stable working environment to increase enterprises' innovativeness and overall performance. Better profitability, competitiveness in both the local and foreign market, and innovativeness could be there if the working environment is stable.

Government's effectiveness to fight and somehow control the deep-rooted political instability and corruption within the public service provision would create conducive environment for enterprises' innovativeness in Ethiopia. Transparent, efficient, and effective public service provision should be there for enterprises to enhance their performance and innovativeness.

Finally, this study concludes that "what is an efficient and effective strategy, corruption, for an individual enterprise may not be at national level". Thus, the societal and livelihood effect of corruption should be studied in detail before advocating greasing effect of this issue on innovativeness of enterprises in Ethiopia.

\section{Limitations and future developments in the field}

Alike any other study, this study has certain limitations that provide opportunities for future research. There are possibilities of reversal causality between corruption and 
political instability because of dynamic relationships between them since one reinforces the other. Additionally, the study has limitation of macro level generalization about innovativeness since the World Bank survey did not include samples from agricultural sector.

\section{Abbreviations}

CD: Coefficient of determination; CFI: Comparative Fit Index; R\&D: Research and development; RMSEA: Root mean squared error of approximation; SEM: Structural equation modeling; SRMR: Standardized root mean squared residual; TLI: Tucker-Lewis Index

\section{Acknowledgements}

The authors thank the World Bank for conducting an intensive enterprise survey and availing the data to the public. This research received no specific grant from any funding agency in the public, commercial, or not-for-profit sectors.

Funding

"Not applicable." The study has not funding support from anybody.

\section{Availability of data and materials}

The study used secondary data collected by the World Bank in 2011 and 2015 from 644 and 848 enterprises in Ethiopia. The data are easily accessible from the Internet for anybody who is interested to do research works in the area.

\section{Authors' contributions}

AS conceived the study, edited the data, performed the analysis and interpretation, and drafted skeleton of the manuscript and critically review the manuscript. MDW contributed in constructing the model, performing the analysis, interpretation of model results, and intensively edit language of the manuscript. All authors approved and read the final manuscript and participated in the critical appraisal as well as revision of the manuscript.

\section{Authors' information}

Arega Shumetie got his BA degree in 2005 from Addis Ababa University, Faculty of Business and Economics, Department of Economics. After serving for three consecutive years in government offices, he did MSc. degree in Agricultural Economics in Haramaya University, College of Agriculture and Environmental Science in 2010. After the MSc, he joined Haramaya University department of Economics to serve as a lecturer and researcher until he started PhD. in 2012. He did PhD. in Agricultural Economics in Haramaya University of Ethiopia and Makerere University of Uganda. The dissertation was on "Effect of Climate Variability on Crop Yield, Income and Rural Labour Displacement of Ethiopia", which was defended on June 20/2017. Arega has a research interest on issues such as economic development and growth, climate change and variability, agricultural productivity, and environmental problems. Mulugeta Damie Watabaji is as Assistant Professor of Supply/Value Chain Management at the Haramaya University, Ethiopia. He is a teaching staff of the Department of Agricultural Economics and Value Chain Management, College of Agriculture and Environmental Science of the same university and Department of Accounting and Finance, College of Business and Economics at same university. He holds a Bachelor Degree in Accounting and Finance and Master of Business Administration (MBA) from the Addis Ababa University, Ethiopia and a PhD Degree from the Division of Agrifood Marketing and Chain Management, Department of Agricultural Economics, Faculty of Bioscience Engineering at Ghent University, Belgium. His areas of research interest are agribusiness value chain management, enterprise development, and enterprises, chains and network innovations.

\section{Competing interests}

Since the data and working material of the research were secondary type, the authors do not have any sort of conflict of interest. The authors declare that they have no competing interests.

\section{Publisher's Note}

Springer Nature remains neutral with regard to jurisdictional claims in published maps and institutional affiliations.

\section{Author details}

${ }^{1}$ Department of Economics, Debre Markos University, Po.Box. 169, Debre Markos, Ethiopia. ${ }^{2}$ Department of Accounting and Finance, Haramaya University, Po.Box. 138, Dire Dawa, Ethiopia.

Received: 11 August 2018 Accepted: 25 April 2019

Published online: 27 May 2019

\section{References}

Abu, N., Abd Karim, M., \& Azman, A. M. (2015). Corruption, political instability and economic development in the economic community of West African States (ECOWAS): Is there a causal relationship? Contemporary Economics, 09(1), 45-60.

Alonso, J. A., \& Garcimartín, C. (2013). The determinants of institutional quality: More on the debate. Journal of International Development, 25(2), 206-226.

Aurora, A., Teixeira, C., \& Luís, G. (2015). Corruption and FDI: Does the use of distinct proxies for corruption matter. Journal of African Business, 16(1-2), 159-179. 
Barasa, L., Knoben, J., Vermeulen, P., Kimuyu, P., \& Kinyanjui, B. (2017). Institutions, resources and innovation in East Africa: A firm level approach. Research Policy, 46(1), 280-291.

Bardhan, P. (1997). Corruption and development: A review of issues. Journal of Economics Literature, 35, 1320-1346.

Bentler, P. M. (1990). Comparative fit indices in structural models. Psychological Bulletin, 107, 238-246.

Bogliacino, F., \& Pianta, M. (2010). Innovation and employment: A reinvestigation using revised Pavitt classes. Research Policy, 39(6), 799-809.

Browne, M. \& Cudeck, R. (1993). Alternative ways to of assessing model fit. In K.A. Bollen \& J.S. Long (Eds.). Testing structural equation models (Pp. 136-162). Newbury park, CA. Sage.

Buyinza, F., \& Bbaale, E. (2013). Access to credit and the effect of credit constraints on the performance of manufacturing firms in the East African region: Micro analysis. International Journal of Economics and Finance, 5(10), 85-99.

Cameron, A. C., \& Trivedi, K. P. (2005). Micro-econometrics Methods and Applications: Cambridge University Press. Cambridge: The Edinburgh Building.

Campbell, N., \& Saha, S. (2013). Corruption, democracy, and Asia-Pacific countries. Journal of the Asia Pacific Economy, 18(2), 290-303.

Carlsson, B. (2006). Internationalization of innovation systems: A survey of the literature. Research Policy, 35, 56-67.

Colin, C. W., \& Abbi, M. K. (2016). The impacts of corruption on firm performance: Some lessons from 40 African countries. Journal of Developmental Entrepreneurship, 21(4), 1650022 (18 pages). World Scientific Publishing Company.

Crespi, G., Chiara, C., \& Jonathan, H. (2008). Productivity, exporting, and the learning-by-exporting hypothesis: Direct evidence from UK firms. Canadian Journal of Economics, 41(2), 619-637.

Crespi, G., \& Zuniga, P. (2011). Innovation and productivity: Evidence from six Latin American countries. World Development, $40(2), 273-290$.

D'Estea, P., Rentocchinib, F., \& Jurado, J. M. V. (2010). Lowering barriers to engage in innovation: Evidence from the Spanish innovation survey. In $8^{\text {th }}$ international triple Helix conference (pp. 1-14).

Daniel, G. (2012). Corruption and small and medium-sized enterprise growth in Cameroon. In African economic conference. Kigali: United Nations Development Programme and Faculty of Economics and Management, University of Yaounde II.

DiRienzo, C., \& Das, J. (2015). Innovation and role of corruption and diversity: A cross-country study. International Journal of Cross Cultural Management, 15(1), 51-72.

Edame, G. (2001). Development, economy and planning in Nigeria. Benin: Harmony Books.

Egbetokun, A., Richmond, A.-A., Oluseye, J., \& Edward, L. (2016). Firm-level innovation in Africa: Overcoming limits and constraints. Innovation and Development, 6(2), 161-174.

Egbetokun, A. A., Siyanbola, W., \& Adeniyi, A. (2007). Indigenous innovation capability in sub-Saharan Africa: A review of the Nigerian situation. In Proceedings of the $5^{\text {th }}$ international symposium on Management of Technology (pp. 1018-1022).

Farzanegan, M. R., \& Witthuhn, S. (2017). Corruption and political stability: Does the youth bulge matter? European Journal of Political Economy, 49(3), 47-70. https://doi.org/10.1016/j.ejpoleco.2016.12.007.

Feng, Y. (1997). Democracy, political stability and economic growth. British Journal of Political Science, 27(3), $391-418$.

Fisman, R., \& Svensson, J. (2007). Are corruption and taxation really harmful to growth? Firm level evidence. Journal of Development Economics, 83, 63-75.

Fjelde, H. (2009). Buying peace? Oil wealth, corruption and civil war, 1985 - 99. Journal of Peace Research, 46, 199-218.

Gayle, A., Candace, A. M., \& Christopher, W. (2012). Political instability, pro-business market reforms and their impacts on national systems of innovation. Research Policy, 41, 638-651.

Globerman, S., \& Shapiro, D. (2003). Governance infrastructure and U.S. foreign direct investment. Journal of International Business Studies, 3(1), 19-39.

Godfred, A. B., Charles, A., \& Mark, E. K. (2018). Financial access and firm productivity in sub-Saharan Africa. Journal of African Business, 19(2), 210-226.

Godin, B. (2013). Invention, diffusion and linear models of innovation. Chairefernanddumont.ucs.inrs.ca, (15), 1-38.

Goedhuys, M., Janz, N., \& Mohnen, P. (2014). Knowledge-based productivity in "low-tech" industries: Evidence from firms in developing countries. Industrial and Corporate Change, 23(1), 1-23.

Goedhuys, M., Pierre, M., \& Tamer, T. (2016). Corruption, innovation and firm growth: Firm-level evidence from Egypt and Tunisia. Eurasian Business Review, Springer; Eurasia Business and Economics Society, 6(3), 299-322.

Gourlay, A. R., \& Seaton, J. S. (2004). UK export behavior at the firm level. Economic Issues, 2.

Hailu, G., Peter, C. B., \& Bonita, L. M. (2005). The influence of place attachment on recreation demand. Journal of Economic Psychology, 26, 581-598.

Halpern, L. (2007). Literature survey on the links between innovation, competition, competitiveness, entry \& exit, irm survival and growth, MICRO-DYN, EU sixth framework programme, working paper, 02/07.

Hammed, A.A. (2018). Corruption, political instability and development Nexus in Africa: A call for sequential policies reforms. (Munich personal RePEc archive) MPRA paper no. 8527. https://mpra.ub.uni-muenchen.de/85277/.

Hancock, G. R., \& Mueller, R. O. (2006). Structural Equation Modeling: A Second Course. Charlotte: Information Age Publishing.

lizuka, M., Mawoko, P. \& Gault, F. (2015). Innovation for development in southern and eastern Africa: Challenges for promoting ST and I policy. UNU-MERIT Policy Brief I.

Jeroen, P. J. D. J., \& Patrick, A. M. V. (2006). Determinants of product innovation in small firms: A comparison across industries. International Business Journal, 24(6), 587-609.

Lambsdorff, J. (2007). The institutional economics of corruption and reform. Cambridge Books Retrieved from http://ideas.repec. org/b/cup/cbooks/9780521872751.html.

Le, P. N. M. (2012). What determines the access to credit by SMEs? A case study in Vietnam. Journal of Management Research, 4(4), 90-115.

Leydesdorff, L., \& Meyer, M. (2006). Triple helix indicators of knowledge-based innovation systems: Introduction to the special issue. Research Policy, 35, 1441-1449.

Lorenzo, D., \& Núñez-cacho, P. (2013). Do family firms have specific barriers to innovation? (pp. 1-36) http://www2.uca.es/serv/ catedra-empresafamiliar/docs/.

Mahagaonkar, P. (2008). Corruption and innovation: A grease or sand relationship? Jena Economic Research Papers, No. $2008,017$.

Makanyeza, C., \& Dzvuke, G. (2015). The influence of innovation on the performance of small and medium enterprises in

Zimbabwe. Journal of African Business, 16(1-2), 198-214. 
Małgorzata, S.L. (2015). Barriers to technological innovation and international market orientation of polish manufacturing enterprises. Pobrane z czasopisma Annales H - Oeconomia. XLIX (3). http://oeconomia.annales.umcs.pl.

Mauro, P. (2004). The persistence of corruption and slow economic growth. International Monetary Fund Staff Papers, $51(1), 1-18$

Megiso, T. S. (2007). Anti-corruption efforts in Ethiopia. In Report submitted by Federal Ethics and Anti-Corruption Commission of Corruption Prevention and Research Department at Global Forum V, Fighting Corruption and Safeguarding Integrity Conference, Sandton, South Africa.

Meon, P. G., \& Sekkat, K. (2005). Does corruption grease or sand the wheels of growth? Public Choice, 122(1-2), 69-97.

Meon, P. G., \& Weill, L. (2010). Is corruption an efficient grease? World Development, 38, 244-259.

Montobbio, F. (2003). Sectoral patterns of technological activity and export market share dynamics, Cambridge. Journal of Economics, 27. https://doi.org/10.1093/cje/27.4.523.

Mowery, D. C., \& Oxley, J. E. (1995). Inward technology transfer and competitiveness: The role of national innovation systems. Cambridge Journal of Economics, 67-93.

Mudombi, S., \& Muchie, M. (2014). An institutional perspective to challenges undermining innovation activities in Africa. Innovation and Development, 4(2), 313-326.

Muok, B. O., \& Kingiri, A. (2015). The role of civil society organizations in low-carbon innovation in Kenya. Innovation and Development, 5(2), 207-223.

Neudorfer, S. N., \& Theuerkauf, G. U. (2014). Buying war not peace: The influence of corruption on the risk of ethnic war. Comparative Political Studies, 47(13), 1856-1886.

Nguyen, N., \& Luu, N. (2013). Determinants of financing pattern and access to formal informal credit: The case of small and medium sized enterprises in Vietnam. Journal of Management Research, 5(2), 240-259.

Oluwaseun, B., \& Faith, A. (2013). Corruption, conflict and sustainable development in African states. The African Symposium: An online journal of the African Educational Research Network, 45(13) ISSN\# 2326-8077.

Osoro, O., Vermeulen, P., Knoben, J., \& Kahyarara, G. (2016). Effects of knowledge sources on firm-level innovation in Tanzania. Innovation and Development, 6(2), 259-280.

Owoye, O., \& Bissessar, N. (2014). Corruption in African countries: A symptom of leadership and institutional failure. Public administration, governance and globalization. Switzerland: Springer International Publishing.

Palangkaraya, A. (2012). The link between innovation and export: Evidence from Australia's small and medium enterprises. ERIA Discussion Paper Series. ERIA-DP-2012-08.

Rodriguez, P., Siegel, D. S., Hillman, A., \& Eden, L. (2006). Three lenses on the multinational enterprise: Politics, corruption, and corporate social responsibility. Journal of International Business Studies. 37, 733-746.

Rupert, H., Jordi, J., Jacques, M., \& Bettina, P. (2014). Does innovation stimulate employment? A firm-level analysis using comparable micro-data from four European countries. International Journal of Industrial Organization, 35, 29-43.

Salami, A., Kamara, A. B., \& Brixiova, Z. (2010). Smallholder agriculture in east Africa: Trends, constraints and opportunities. Tunis: African Development Bank.

Sergey, A., \& William, S. S. (2009). Entrepreneurship, innovation, and corruption. Journal of Business Venturing, 24, 465-476.

Tamer, T. (2016). Is corruption "greasing" or "sanding" the wheels of innovation of firms in Mena? Working paper 982. Economic Research Forum.

Tarus, D. K., \& Sitienei, E. K. (2015). Intellectual capital and innovativeness in software development firms: The moderating role of firm size. Journal of African Business, 16(1-2), 48-65.

Varsakelis, N. (2006). Education, political institutions and innovative activity: a crosscountry empirical investigation. Research Policy, 35, 1083-1090.

Waldemar, F. S. (2012). New products and corruption: Evidence from Indian firms. The Developing Economies, 50(3), 268-284.

Williams, C. C., \& Abbi, M. K. (2016). The impacts of corruption on firm performance: Some lessons from 40 African countries. Journal of Developmental Entrepreneurship, 21(4). https://doi.org/10.1142/S1084946716500229.

World Bank, (1997), Helping countries to combat corruption: The role of the World Bank. The World bank: Washington DC.

World Bank, (2015). Enterprise survey, what business experience, Ethiopian 2015, country profile: The, IBRD-IDA World Bank Group.

Zhang, Y., Cao, L., \& Vaughn, M. S. (2009). Social support and corruption: Structural determinants of corruption in the world. Australian \& New Zealand Journal of Criminology, 42(2), 204-217.

\section{Submit your manuscript to a SpringerOpen ${ }^{\circ}$ journal and benefit from:}

- Convenient online submission

- Rigorous peer review

- Open access: articles freely available online

- High visibility within the field

- Retaining the copyright to your article

Submit your next manuscript at $\boldsymbol{\Delta}$ springeropen.com 